\title{
Anatomy and Cellular Constituents of the Human Olfactory Mucosa: A Review
}

\author{
C. Russell Chen ${ }^{1}$ Carolina Kachramanoglou ${ }^{1}$ Daqing $\mathrm{Li}^{1} \quad$ Peter Andrews $^{2}$ David Choi ${ }^{1}$
} 1 Department of Neurosurgery, National Hospital for Neurology and
Neurosurgery, Queen Square, London, United Kingdom
2 Department of ENT, Royal National Throat Nose and Ear Hospital,
London, United Kingdom

\begin{abstract}
Address for correspondence Dr. Ching Wei Russell Chen, MD, Albert Einstein College of Medicine, 1300 Morris Park Avenue, Bronx, NY 10461, United States (e-mail: chingwei.chen@med.einstein.yu.edu).
\end{abstract}

J Neurol Surg B 2014;75:293-300.

\author{
Abstract \\ Keywords \\ - olfactory mucosa \\ - olfactory system \\ - olfactory ensheathing \\ cells \\ - spinal cord repair
}

Studies using animal models have recently suggested that the olfactory mucosa may be a source of cells capable of stimulating and contributing to complex neurologic regeneration. Several groups have already transplanted cell derivatives from the olfactory mucosa into injury models, and the results so far have been promising. To fully appreciate the meaning of these experiments, a better understanding of the cellular biology and physiology of the olfactory system is necessary. It is therefore of utmost importance for us to first identify and understand its constituents.

\section{Introduction}

The olfactory mucosa is the part of the nasal mucosa that carries the specialized sensory organ for the modality of smell. Its structure, function, and physiology are unique yet poorly understood. Diseases associated with the olfactory system lead to an array of complex secondary presentations that are also not well understood including complaints of quality of life, mood changes, and depression. ${ }^{1}$

It is well known that the olfactory system is one of the two areas in the central nervous system (CNS)-the other being the hippocampus-where neuronal regeneration occurs. Yet in the clinical setting, the physician is still unable to exploit this exceptional characteristic for the patient's benefit. Furthermore, the lack of understanding of the olfactory mucosa renders the differential diagnosis for anosmia to range from entorhinal disease to complex CNS disorders such as Parkinson disease and Alzheimer disease. A better understanding of the olfactory mucosa is necessary for olfactory function to translate into accurate, useful clinical indicators for pathologic processes.

The olfactory mucosa has recently come under scrutiny as a potential source for cells that might be used for human tissue repair, and several groups have transplanted cell derivatives of the mucosa into injury models, often without really understanding the true constituents of the mucosa and transplant. Olfactory ensheathing cells in particular have attracted much attention, due to promising results in animal models of spinal cord repair ${ }^{2,3}$ and the preliminary confirmation of safety in patients. ${ }^{4}$ However, it is important to better understand the cellular components of cell cultures derived from the mucosa, and this in turn requires a better understanding of the olfactory mucosa itself.

\section{Clinical and Developmental Anatomy}

\section{Gross and Clinical Anatomy}

Upon gross examination, the human olfactory mucosa appears slightly yellow and without a distinctive hue as seen in rodents. It is generally agreed that it is located high in the nasal cavity, and specifically, it has been suggested to be concentrated in the posterosuperior aspect of the nasal cavity, in the two clefts formed superiorly by the cribriform plate, medially by the nasal septum, and laterally by the superior meatus. ${ }^{5}$ Laterally, it can also be found in the posterior aspect of the superior turbinate and as far anteriorly as above and below the middle turbinate.,

In the clinical setting, gross examination of the olfactory mucosa may lack diagnostic value. First, the distribution of the olfactory mucosa is heterogeneous, thus making it difficult to distinguish from respiratory mucosa. ${ }^{8}$ Second, received

August 11, 2012

accepted after revision

October 7, 2013

published online

June 26, 2014 (c) 2014 Georg Thieme Verlag KG Stuttgart · New York
DOI http://dx.doi.org/ 10.1055/s-0033-1361837. ISSN 2193-6331. 
throughout life, respiratory epithelium gradually expands and replaces olfactory epithelium (OE). ${ }^{8}$ And third, the olfactory tissue possesses multiple pathways for defense and regeneration ${ }^{9}$ that makes morphological evaluation at any one point in time uninformative of overall mucosal health. The retrospective study conducted by Holbrook et al strongly implicated that rather than evaluating the morphological status of the OE, it is much more useful to examine the health of olfactory axons to determine the overall olfactory function. ${ }^{10}$

\section{Developmental Anatomy}

The $\mathrm{OE}$ is formed by two olfactory placodes that are ectodermal thickenings in the rostrolateral region of the embryonic head. ${ }^{11-16}$ In humans, the $\mathrm{OE}$ is well delineated by day 37 postconception (pc). ${ }^{17}$ The olfactory receptor neurons (ORNs) undergo ciliogenesis during 9 weeks pc, and by 11 weeks pc, there is complete morphological differentiation of ORNs and development of Bowman glands. ${ }^{18}$ Olfactory marker protein (OMP) can first be detected in ORNs at 24 weeks $\mathrm{pc}^{19}$ and in the olfactory bulbs (OBs) at 32 weeks pc, ${ }^{20}$ but it has been reported that preterm infants born at 29 weeks pc exhibit clear behavioral responses to strong odorants. ${ }^{21,22}$ In rodents, OMP is generally accepted as a marker of maturity due to its presence in differentiated ORNs, ${ }^{23,24}$ but this criterion is obviously unsuitable for humans. The $\mathrm{OE}$ continues to develop after organogenesis and becomes morphologically identical to adult epithelium at late gestation. ${ }^{25}$

The physiology of fetal $\mathrm{OE}$ is worth mentioning here. $\mathrm{Gu}$ et $\mathrm{al}^{26}$ found high levels of cytochrome P450 enzymes in the olfactory mucosa of developing human fetal tissue. High expression of these enzymes suggests that the olfactory mucosa may be deeply and intricately involved in the metabolism of maternally derived compounds; specifically, the olfactory mucosa may be a preferred target of certain toxic compounds. The recent quantitative analysis of the spatial distribution of UDP-glucuronosyltransferases, enzymes involved in detoxification, in mouse neuro-olfactory tissue further implies the role of $\mathrm{OE}$ in detoxification. ${ }^{27}$ In addition to playing important metabolic roles, fetal olfactory tissue has been implicated to have immunologic functions by the discovery of Iba1- and annexin A3-immunopositive cells in the peripheral olfactory nerves of adult rats and adult cats. ${ }^{28}$ Iba1- and annexin A3-immunopositivity suggests the presence of microglia/macrophages. These cells may be important in immunologic protection of the brain from infectious and toxic agents. ${ }^{28}$

\section{Histology}

The tissue lining the nasal cavity is composed of four types of epithelium. From outermost to innermost, they are (1) stratified squamous epithelium with numerous hair follicles, (2) transitional, cuboid, or columnar epithelium with no hair follicles, (3) ciliated pseudostratified columnar epithelium, and finally, (4) respiratory epithelium that consists of ciliated columnar cells, mucus-secreting goblet cells, and small basophilic cells believed to be stem cells. ${ }^{29-31}$ Upon microscopic examination, one finds that healthy olfactory mucosa is generally thicker and more cellular than respiratory mucosa. ${ }^{32}$

The olfactory mucosa is composed of three primary components: epithelium, basement membrane, and lamina propria. Adult $\mathrm{OE}$ can be identified using antibodies against trace amine-associated receptors and OMP; developing epithelial markers include epidermal growth factor receptors, transforming growth factor $\alpha$, and nerve growth factor $\beta .^{33,34}$ The basal lamina, or basement membrane, lies beneath the epithelium and is usually a well-defined homogeneous structure $^{35}$ On the other side of the basement membrane lies a thick lamina propria that contains mucous and serous cells, nerve fascicles, pigment cells, lymphoid cells, and blood capillaries ( $\mathbf{F i g . 1}$ ). ${ }^{36-38}$

Before moving on to the discussion of different cell types, one other tissue structure worth specific mention is the olfactory pit, formed from invagination of $\mathrm{OE}$ into the underlying connective tissue. These structures vary from 150 to $200 \mu \mathrm{m}$ in depth and 50 to $100 \mu \mathrm{m}$ in diameter. ${ }^{39}$ They are hypothesized to prolong odorant association with receptors by creating a pouched environment or to provide specific niches for specialized neurons that have yet to be discovered. ${ }^{39}$ Like Bowman glands, olfactory pits are confined to the $\mathrm{OE}$ and are thus useful markers for distinction from respiratory epithelium. ${ }^{40}$

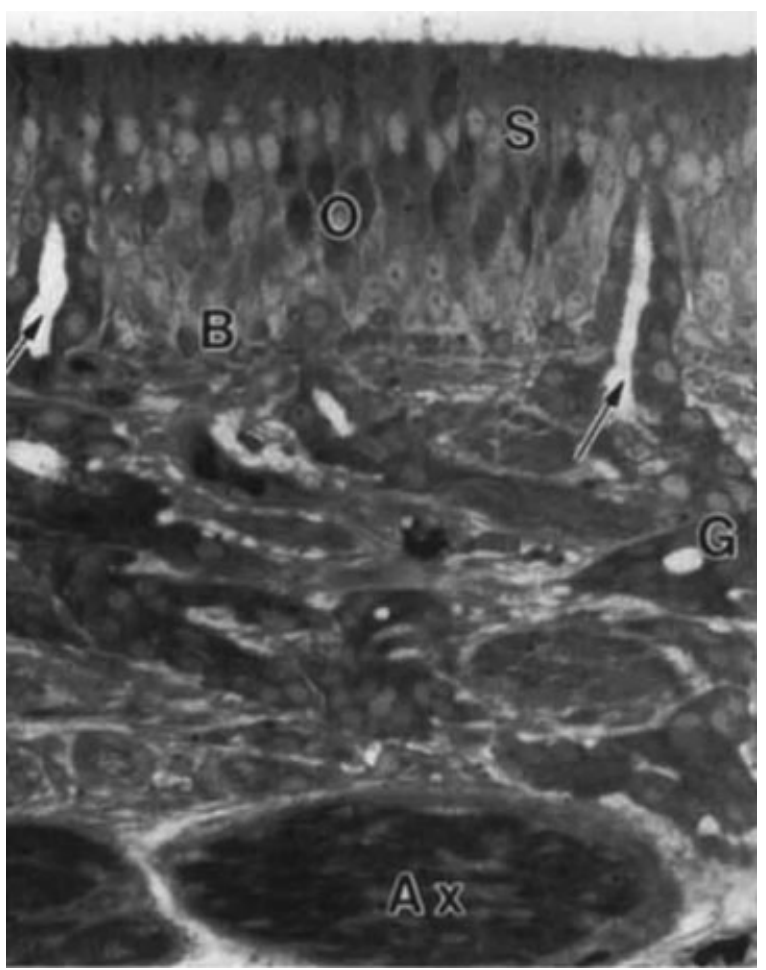

Fig. 1 Light micrograph thick section $(1 \mu \mathrm{m})$ of human olfactory mucosa. The olfactory epithelium contains supporting $(S)$, receptors $(\mathrm{O})$, and basal (B) cells. The lamina propria contains olfactory axon fascicles (Ax) and Bowman glands (G), whose secretory ducts open to the mucosal surface (arrows). $\times 450$. (Reprinted with permission from Morrison EE, Costanzo RM. Morphology of olfactory epithelium in humans and other vertebrates. Microsc Res Tech 1992;23(1):49-61.) 


\section{Cell Types in the Olfactory Mucosa}

\section{Epithelium}

The $\mathrm{OE}$ is composed of five principal cell types: olfactory receptor neurons, sustentacular cells, basal cells, microvillar cells, and fingerlike microvilli cells. ${ }^{30,41-44}$

\section{Olfactory Receptor Neurons}

It is well known that ORNs are sensory cells specialized for detecting odorants. In humans, ORNs can be found at various stages of maturity and are interspersed with sustentacular cells. ${ }^{45}$ The nuclei of ORNs are elliptical and usually darkly stained, the cell bodies are round or oval, $\sim 4$ to $6 \mu \mathrm{m}$ in diameter, and the dendrites ascend in between sustentacular cells to terminate in a knob-bearing olfactory cilia, with each receptor cell having 10 to 20 cilia. $^{46-48}$ Gap junctions are present between ORNs, and they are believed to play a role in facilitating the development and turnover of tissue. ${ }^{49}$ The morphology of the knob is flat or dome-shaped, not bulblike. And cilia lie in the long axis of the olfactory cell, perpendicular to the epithelial surface rather than parallel as described in some nonhuman species. ${ }^{41}$ Olfactory knobs and cilia in a nonparallel orientation under electron microscopy can be used to determine the presence of ORNs within the $\mathrm{OE}^{6}$

Olfactory sensory cells can be marked by growth-associated protein-43), ${ }^{50} \beta$-tubulin 3, ${ }^{6,51,52} \mathrm{MAP}-1 \mathrm{~B},{ }^{53}$ neuron-specific enolase, ${ }^{54}$ neurofilament protein, ${ }^{54}$ neural cell adhesive molecule (NCAM) ${ }^{55}$ neuron-specific tubulin, ${ }^{56}$ PGP $9.5,{ }^{57,58}$ and OMP. ${ }^{59-61}$ MAP-1B and NCAM identify dendrites and axons of ORNs and label nerve bundles intensely. ${ }^{53}$ Carnosine-like immunoreactivity has also been demonstrated in ORNs. ${ }^{62}$

\section{Sustentacular Cells}

Sustentacular cells are irregular columnar cells with large vertically elongated euchromatic nuclei and multiple long microvilli. ${ }^{41,63}$ Most sustentacular cells lie superficial to the soma of ORNs, and their cytoplasm contains many mitochondria, granular and agranular endoplasmic reticulum. ${ }^{63}$ Many findings suggest that sustentacular cells play an important role in the regulation of ORN homeostasis and proliferation including the discovery of tight junctions between sustentacular cells and ORNs and complex calcium signaling in mouse sustentacular cells. ${ }^{31,46,64}$

SUS- 1 and SUS- 4 have been described as useful antibodies for labeling sustentacular cells in the rat. ${ }^{65,66}$ Using electron microscopy, Pixley et al ${ }^{67}$ found that $1 \mathrm{~F} 4$, an immunoglobulin (Ig)M kappa monoclonal antibody, selectively labeled the microvilli of sustentacular cells and ductal cells of Bowman glands in the rat. They also bind to the microvilli and cilia of ciliated but not secretory cells in the respiratory epithelium. ${ }^{67}$ More recently, Minovi et $\mathrm{al}^{68}$ found that nestin expression is constantly detectable in the apical protuberances of sustentacular cells in healthy adults. But in the decline of olfactory function, nestin expression can be decreased. ${ }^{68}$ These results suggest the possibility of nestin and 1F4 as markers for sustentacular cells and indicator of $\mathrm{OE}$.
Bowman glands

It is known that Bowman glands are branched tubuloalveolar structures that lie beneath the OE and secrete onto the epithelial surface through narrow ducts. ${ }^{31}$ In addition to bathing the dendritic endings and cilia of ORNs, thus allowing odorant diffusion to sensory receptors, the secretion is suggested to play important immunologic functions. Constituents of the secretory immune system including IgA, IgM and J chain, have been localized in the acinar and duct cells of Bowman glands and in the mucociliary complex. ${ }^{69}$ Lactoferrin and lysozyme, two antimicrobial proteins, have also been found. ${ }^{69}$

Olfactory ensheathing cells

Olfactory ensheathing cells were first described by Golgi and by Blanes when they observed the glial populations in the olfactory bulbs of mammals. ${ }^{70,71}$ In addition to residing in the first two layers of the $\mathrm{OB}$, these cells are found in the $\mathrm{OE}$, where the mesaxon of each ensheathing cell encloses densely packed bundles of unmyelinated axons (fila olfactoria) projecting from ORNs to the OBs. ${ }^{12,14,72-76}$ Although OECs are found in the interstices between glomeruli in the $\mathrm{OB}$, their processes never extend into the glomeruli. $^{72,77}$

As mentioned previously, the $\mathrm{OE}$ develops from the olfactory placodes. The olfactory bulbs, in contrast, develop from the neural tube. Because of the dual developmental origin of the structures containing OECs, the origin of OECs is still debated. There is increasing evidence today that the OECs develop from the olfactory placodes. As they mature, OEC progenitor cells accompany ORN axons toward the OB by following a gradient created by soluble factors secreted by the target tissue. This idea is further supported by the nonimmunopositivity of OECs for A4 antibody.

Morphologically, olfactory ensheathing cell progenitors can be clearly distinguished by their dark round appearance, mode of association with axons, and ultrastructural characteristics. $^{14-16,73,78}$ Their lobulated nucleus contains patchy chromatin beneath the nuclear envelope and one or two nucleoli. As they mature, they acquire an elongated morphology with thin laminar processes that enfold small axonal bundles. ${ }^{16}$ In the adult, OECs have a fusiform morphology with the perikarya aligned along olfactory fascicles. ${ }^{73,78}$ Their nuclei are indented with uniformly distributed, yet slightly clumped chromatin below the nuclear membrane. In the cytoplasm, free ribosomes and large inclusion bodies are abundant. In comparison with astrocytes, OECs are electron denser and have intermediate filaments that are scattered rather than arranged in bundles. ${ }^{74,79,80}$ The plasma membrane at the terminal ends of processes also lack the orthogonal arrays of intramembranous particles that are observed in those of astrocytes. $^{73,74,76,81,82}$

To identify OECs, numerous markers have been suggested: platelet-derived growth factors, ${ }^{83}$ neuropeptide $\mathrm{Y}^{84} \mathrm{~S} 100,{ }^{85,86}$ glia-derived nexin (a neurite-promoting molecule), ${ }^{87,88}$ L1 (cell adhesion molecule), ${ }^{89}$ laminin, ${ }^{90-92}$ polysialic acid-containing molecule, ${ }^{93} \mathrm{NCAM}^{89}$ and 
p75NGFR. The expression of p75NGFR is stronger in neonatal OECs and almost undetectable, but not absent, in the adult. ${ }^{86,93-95}$ Also, it has been found that NCAM and L1 are exclusively present in the part of glial membrane that associates with axons. ${ }^{89}$ To distinguish OECs from Schwann cells, Boyd et $\mathrm{al}^{96}$ reported that OECs exclusively express calponin. Tomé et $\mathrm{al}^{97}{ }^{97}$ however, found calponin to be heterogeneously expressed by neonatal mucosal connective tissue but not neonatal OECs, embryonic OECs, and neonatal Schwann cells.

In recent years, olfactory ensheathing cells (OECs) have received much attention from the scientific community due to their application in regenerative medicine. It was suggested a few years ago that OECs from OE differ from those obtained from olfactory bulbs. ${ }^{98}$ Notably, OECs from olfactory mucosa overexpress genes characteristic of wound healing and regulation of extracellular matrix, whereas OECs from olfactory bulbs express genes suggestive of nervous system development. ${ }^{98}$ Within the population of OECs from olfactory bulbs, two subpopulations different in biophysical property and gap junction connectivity have also been found. ${ }^{99}$

In vivo, OECs form a matrix of cellular projections surrounding axons, unique among glia, and express high levels of connexin- $43 .{ }^{99}$ In the transitional zone between the peripheral nervous system and CNS, OECs have been found to interact freely with astrocytes and not to induce astrocytosis, which is a major difference between OECs and Schwann cells. ${ }^{100,101}$ This property has been suggested to contribute to the ability of OECs to promote neural regeneration. ${ }^{100}$ It has recently been found that OECs also secrete neurotrophic factors (e.g., NGF 74 and 75) that promote neurite growth. ${ }^{102,103}$

\section{Basal Cells}

It is believed that steady loss and replacement of ORNs and sustentacular cells throughout life is a normal process, and basal cells that lie above the basement membrane are the stem cells in the $\mathrm{OE}$ that divide to give rise to new neural and supporting cells. ${ }^{104-107}$ In the rat it is well known that there are two basal cell types, (small) globose basal cells (GBCs) and horizontal basal cells (HBCs), and that mature and immature ORNs are organized in a highly laminar fashion with mature cells closer to the apical surface. In the human, however, there appears to exist only one basal cell type that morphologically resembles the GBCs in the rat. ${ }^{53}$ These cells are usually 5 to $7 \mu \mathrm{m}$ in diameter and have a rough cellular surface upon examination by electron microscopy. ${ }^{46}$

Intermediate filament proteins have been markers of interest in the past. It was previously assumed that nestin, one type of intermediate filament protein, was a specific marker for OE stem cells. ${ }^{108,109}$ Using a bank of antibodies, Doyle et $\mathrm{al}^{110}$ found that nestin is actually expressed in the axonal ends and inferior processes of OE sustentacular cells in the basal compartment of the epithelium. Hahn et al ${ }^{53}$ further investigated the expression of cytokeratin-5, another class of intermediate filament proteins, in human $\mathrm{OE}$, but disappointingly, the staining showed that cytokeratin is expressed not only in the first layer of basal cells closest to the basal lamina but also in the cells above them.

It has been suggested that $\mathrm{Ki}-67$, a cell cycle marker, be used as criterion for putative neural precursors in human $\mathrm{OE}^{53}$ The limitation of this marker is that $20 \%$ of the labeled cells reside in layers above the basal one, and not all cells positive for Ki-67 are positive for p75NGFR, a protein known to be expressed in basal cells as well as OECs. ${ }^{53,111,112}$ Currently, there is still no known marker that exclusively labels human OE stem cells.

Whether HBCs or GBCs are the stem cells in the rat that give rise to the other or to the neural and nonneural cells in the OE has been a subject of debate. ${ }^{104,113-118}$ The following section reviews the histology and proposed function of these two cell types.

\section{Horizontal Basal Cells}

Horizontal basal cells (HBCs) lie deepest in the $\mathrm{OE}$ and closest to the basement membrane, and they maintain a flat morphology. ${ }^{119}$ They are relatively quiescent and are thought to divide only occasionally to give rise to GBCs, which are assumed to then give rise to ORNs and sustentacular cells. ${ }^{114,120,121}$ In the event of severe damage to the $\mathrm{OE}$, HBCs have been found to divide more frequently to give rise to multiple cell types. ${ }^{114,120}$ This also potentially accelerates tissue repair. It has been suggested that HBCs can give rise to OECs. ${ }^{113}$

\section{Globose Basal Cells}

Globose basal cells (GBCs) lie above the HBCs and have a rounder morphology. ${ }^{119}$ They can be labeled using cytokeratin, p75NGFR, and GBC-1, a monoclonal antibody that exclusively labels GBCs. ${ }^{66,68,122}$ In animal models, GBCs are found to be necessary for regeneration of $\mathrm{OE}$ after lesion. ${ }^{123}$ Their ability to give rise to either neurons, nonneurons, or both cell types in the OE proves that they are multipotent cells. ${ }^{124}$

\section{Microvillar Cells}

Microvillar cells are located near epithelial surface. ${ }^{42}$ Although they are flask-shaped with a tuft of blunt microvilli that extends into the mucus layer of the epithelium, a thin axon-like cytoplasmic process extends from the basal pole of these cells and travels through the epithelium toward the lamina propria, rendering a bipolar morphology. ${ }^{42}$ Microvillar cells are positive for spot-35 proteins, a type of neuron-specific protein. ${ }^{125}$ Experiments tracing the flow of enzymes further show these cells to be connected to the olfactory bulbs. ${ }^{126}$ Microvillar cells may very well represent a second morphologically distinct class of chemoreceptors in the olfactory mucosa. ${ }^{42,125,126}$ But it has also been demonstrated that a loss of microvillar cells does not affect olfactory function. ${ }^{127}$

\section{Fingerlike Microvilli Cells}

One report from Ota ${ }^{44}$ described a fifth type cell in the $\mathrm{OE}$, and this cell type was found only after the disappearance of the olfactory cilial mat following resection of the olfactory bulbs. Transmission electron microscopy observation reveals that 
the microvilli of these cells are characterized by a specific core structure consisting of microfilament bundles absent in the microvillar cells. Observing a disconnection between these cells and the postganglionic fibers of the trigeminal nerve and the olfactory bulbs, the author suggests that the fifth type cell could be a mechanoreceptor for a sensory system that is nonolfactory.

\section{Lamina Propria}

The lamina propria of the olfactory mucosa contains numerous cell types and structures including endothelial cells that make up the blood vessels, Schwann cells that myelinate processes of sensory neurons, glandular cells of Bowman glands, and stem cells, which have become of significant interest in recent years.

Lamina propria-derived stem cells (LPSCs) have been shown to grow in large numbers and to differentiate into neural and nonneural cell types both in vitro and in vivo. ${ }^{128}$ This is a feature not observed in neurosphere-derived stem cells. ${ }^{129}$ Immunomarkers and flow cytometry also suggest that these cells have little in common with neural stem cells and hematopoietic stem cells. ${ }^{129}$

Studies have shown that LPSCs may have vast replicative potential because they can generate dopaminergic cells after transplantation in a rat model of Parkinson disease and can also give rise to mesodermal cell types. ${ }^{128,130}$ For this reason, these residents of lamina propria have been referred to as mesenchymal(-like) stem cells.

\section{Olfactory Mucosa in Culture}

In explant cultures of human $\mathrm{OE}$, two cell types are found to have p75NGFR immunoreactivity. ${ }^{53}$ The first type is found to have a round to polygonal morphology, and they are immunopositive for Ki-67 and negative for glial fibrillar acidic protein (GFAP). These cells are hypothesized to be equivalent to $\mathrm{OE}$ basal cells. The other type is spindle-shaped and immunopositive for GFAP. Interestingly, these cells are found around the edges of the epithelial sheets that grow out of the explants. $^{53}$

Cells positive for OMP have round or oval cell bodies and possess a bipolar morphology, as do in vivo ORNs. It has been demonstrated that ORNs in dissociated cultures can respond to odorant stimulation by changes in intracellular calcium even if their cellular morphologies appear immature. ${ }^{131}$

In vitro, neonatal human $\mathrm{OEC}$ from $\mathrm{OB}$ have been found to express the glial markers S100, GFAP, p75NGFR, ErbB1-2-3 receptors, but not ErbB4, and neuregulin (NRG)-1. ${ }^{132}$ Depending on the isoform, NRG-1 can be found either in the nucleus or cytoplasm. ${ }^{133}$

The ultrastructure of OECs remains the same in vivo and in vitro, but in animal models, the morphology of OECs can vary tremendously depending on the age of the tissue donor and the presence or absence of serum in the culture medium. ${ }^{74,134,135}$ When cultured from mouse embryos and grown in medium with serum, they appear flat, bipolar, or tripolar. In chemically defined medium, cells change from flat to bipolar spindly, tripolar, or stellate. ${ }^{135}$ When cultured from neonatal rodent epithelium in serum-containing medium, most of the cells are flat with extended cytoplasm; the rest are bipolar or tripolar with long and thin processes. ${ }^{74,136,137}$ Moving these cells to a serum-free media results in an increase of cells with a bipolar or multiprocess appearance. ${ }^{137,138}$ Experiments using culture of OECs from rat OB have also been done. Most of these cells (>94\%) are flattened and exhibit a fibroblast-like morphology when cultured in serum-containing medium. ${ }^{93,94}$ When moved to a serumfree environment, a new population with a spindly morphology emerges. ${ }^{93,94}$

Coculturing with neurons also changes the morphology of OECs, but the change depends on axonal contact and seems to be independent of age of tissue donor and culture conditions. In the presence of axonal contact, OECs acquire a bipolar spindly appearance and are able to ensheathe individual axons. ${ }^{139-142}$ Interestingly, when cocultured with myelinated dorsal root ganglion neurons, OECs form myelin sheaths around the axons of these cells. ${ }^{140}$

\section{Conclusion}

The olfactory mucosa is a highly organized tissue, unique and fit for its purpose. It is possible to isolate many different types of cells including stem cells and olfactory ensheathing cells, and culture them for possible applications in tissue repair. However, it is clear that there are major differences in the numbers and types of cells that can be obtained from cultures of human and rodent samples of mucosa, and we need to study these differences more closely in in vitro tissue culture and in in vivo models. We need to study how cell culture yield changes with patient age, smoking, pollution, and the presence of chronic inflammatory diseases of the nose, as well as to validate culture to good manufacturing practices standards. The positive experimental models of repair using cell therapies are outside the scope of this article, but many show promise, and it is necessary therefore to turn the spotlight on the nature of the cells we are using for cellular therapies derived from olfactory mucosa.

\section{Acknowledgments}

We acknowledge funding from the European Research Council and support from the National Institute for Health Research University College London Hospitals Biomedical Research Centre.

\section{References}

1 Nordin S, Brämerson A. Complaints of olfactory disorders: epidemiology, assessment and clinical implications. Curr Opin Allergy Clin Immunol 2008;8(1):10-15

2 Keyvan-Fouladi N, Raisman G, Li Y. Functional repair of the corticospinal tract by delayed transplantation of olfactory ensheathing cells in adult rats. J Neurosci 2003;23(28):9428-9434

3 Raisman G. Olfactory ensheathing cells-another miracle cure for spinal cord injury? Nat Rev Neurosci 2001;2(5):369-375

4 Mackay-Sim A, Féron F, Cochrane J, et al. Autologous olfactory ensheathing cell transplantation in human paraplegia: a 3-year clinical trial. Brain 2008;131(Pt 9):2376-2386

5 Seiden AM. Taste and Smell Disorders. New York, NY: Thieme; 1997 
6 Féron F, Perry C, McGrath JJ, Mackay-Sim A. New techniques for biopsy and culture of human olfactory epithelial neurons. Arch Otolaryngol Head Neck Surg 1998;124(8):861-866

7 Leopold DA, Hummel T, Schwob JE, Hong SC, Knecht M, Kobal G. Anterior distribution of human olfactory epithelium. Laryngoscope 2000;110(3 Pt 1):417-421

8 Paik SI, Lehman MN, Seiden AM, Duncan HJ, Smith DV. Human olfactory biopsy. The influence of age and receptor distribution. Arch Otolaryngol Head Neck Surg 1992;118(7):731-738

9 Watelet JB, Strolin-Benedetti M, Whomsley R. Defence mechanisms of olfactory neuro-epithelium: mucosa regeneration, metabolising enzymes and transporters. B-ENT 2009;5(Suppl 13):21-37

10 Holbrook EH, Leopold DA, Schwob JE. Abnormalities of axon growth in human olfactory mucosa. Laryngoscope 2005; 115(12):2144-2154

11 Cuschieri A, Bannister LH. The development of the olfactory mucosa in the mouse: light microscopy. J Anat 1975;119(Pt 2): 277-286

12 Cuschieri A, Bannister LH. The development of the olfactory mucosa in the mouse: electron microscopy. J Anat 1975;119(Pt 3):471-498

13 Getchell TV, Bartoshuk LM, Doty RL, Snow JB. Smell and Taste in Health and Disease. New York, NY: Raven Press; 1991

14 Farbman AI, Squinto LM. Early development of olfactory receptor cell axons. Brain Res 1985;351(2):205-213

15 Marin-Padilla M, Amieva MR. Early neurogenesis of the mouse olfactory nerve: Golgi and electron microscopic studies. J Comp Neurol 1989;288(2):339-352

16 Valverde F, Santacana M, Heredia M. Formation of an olfactory glomerulus: morphological aspects of development and organization. Neuroscience 1992;49(2):255-275

17 Bossy J. Development of olfactory and related structures in staged human embryos. Anat Embryol (Berl) 1980;161(2):225-236

18 Pyatkina GA. Development of the olfactory epithelium in man. Z Mikrosk Anat Forsch 1982;96(2):361-372

19 Johnson EW, Eller PM, Jafek BW. Distribution of OMP-, PGP 9.5and CaBP-like immunoreactive chemoreceptor neurons in the developing human olfactory epithelium. Anat Embryol (Berl) 1995;191(4):311-317

20 Chuah MI, Zheng DR. The human primary olfactory pathway: fine structural and cytochemical aspects during development and in adults. Microsc Res Tech 1992;23(1):76-85

21 Sarnat HB. Olfactory reflexes in the newborn infant. J Pediatr 1978;92(4):624-626

22 Winberg J, Porter RH. Olfaction and human neonatal behaviour: clinical implications. Acta Paediatr 1998;87(1):6-10

23 Farbman AI, Margolis FL. Olfactory marker protein during ontogeny: immunohistochemical localization. Dev Biol 1980;74(1): 205-215

24 Weiler E, Benali A. Olfactory epithelia differentially express neuronal markers. J Neurocytol 2005;34(3-5):217-240

25 Kimura M, Umehara T, Udagawa J, Kawauchi H, Otani H. Development of olfactory epithelium in the human fetus: scanning electron microscopic observations. Congenit Anom (Kyoto) 2009; 49(3):102-107

26 Gu J, Su T, Chen Y, Zhang QY, Ding X. Expression of biotransformation enzymes in human fetal olfactory mucosa: potential roles in developmental toxicity. Toxicol Appl Pharmacol 2000;165(2): 158-162

27 Heydel J-M, Holsztynska EJ, Legendre A, Thiebaud N, Artur Y, Le Bon A-M. UDP-glucuronosyltransferases (UGTs) in neuro-olfactory tissues: expression, regulation, and function. Drug Metab Rev 2010;42(1):74-97

28 Smithson LJ, Kawaja MD. Microglial/macrophage cells in mammalian olfactory nerve fascicles. J Neurosci Res 2010;88(4):858-865

29 Kelly DE, Wood RL, Enders AC. Bailey's Textbook of Microscopic Anatomy. Baltimore, MD: Williams and Wilkins; 1984
30 Jafek BW, Murrow B, Michaels R, Restrepo D, Linschoten M. Biopsies of human olfactory epithelium. Chem Senses 2002; 27(7):623-628

31 Ross MH, Kaye GI, Pawlina W. Histology: A Text and Atlas. 4th ed. Philadelphia, PA: Lippincott Williams \& Wilkins; 2003

32 Standring S, Borley NR. Gray's Anatomy: The Anatomical Basis of Clinical Practice. Madrid, Spain: Churchill Livingstone; 2008

33 Carnicelli V, Santoro A, Sellari-Franceschini S, Berrettini S, Zucchi R. Expression of trace amine-associated receptors in human nasal mucosa. Chemosens Percep 2010;3(2):99-107

34 Elmas C, Erdoğan D, Ozoğul C. Expression of growth factors in fetal human olfactory mucosa during development. Growth Dev Aging 2003;67(1):11-25

35 Petruson B, Hansson HA, Karlsson G. Structural and functional aspects of cells in the nasal mucociliary system. Arch Otolaryngol 1984;110(9):576-581

36 Fawcett DW, Raviola E. Bloom and Fawcett, a Textbook of Histology. New York, NY: Chapman \& Hall; 1994

37 Kratzing JE. The anatomy and histology of the nasal cavity of the koala (Phascolarctos cinereus). J Anat 1984;138(Pt 1):55-65

38 Lovell MA, Jafek BW, Moran DT, Rowley JC III. Biopsy of human olfactory mucosa. An instrument and a technique. Arch Otolaryngol 1982;108(4):247-249

39 Feng WH, Kauer JS, Adelman L, Talamo BR. New structure, the "olfactory pit," in human olfactory mucosa. J Comp Neurol 1997; 378(4):443-453

40 Nakashima T, Kimmelman CP, Snow JB Jr. Structure of human fetal and adult olfactory neuroepithelium. Arch Otolaryngol 1984; 110(10):641-646

41 Polyzonis BM, Kafandaris PM, Gigis PI, Demetriou T. An electron microscopic study of human olfactory mucosa. J Anat 1979; 128(Pt 1):77-83

42 Moran DT, Rowley JC III, Jafek BW. Electron microscopy of human olfactory epithelium reveals a new cell type: the microvillar cell. Brain Res 1982;253(1-2):39-46

43 Morrison EE, Costanzo RM. Morphology of olfactory epithelium in humans and other vertebrates. Microsc Res Tech 1992;23(1):49-61

44 Ota Y. Study of the fifth-type cell in the olfactory epithelium. [in Japanese]. Nippon Jibiinkoka Gakkai Kaiho 1998;101(10): 1234-1249

45 Schwob JE. Neural regeneration and the peripheral olfactory system. Anat Rec 2002;269(1):33-49

46 Morrison EE, Costanzo RM. Morphology of the human olfactory epithelium. J Comp Neurol 1990;297(1):1-13

47 Bloom G, Engström H. The structure of the epithelial surface in the olfactory region. Exp Cell Res 1952;3(4):699-701

48 Ganong WF. Review of Medical Physiology. 22nd ed. New Yori, NY: McGraw-Hill Medical; 2005

49 Delay RJ, Dionne VE. Coupling between sensory neurons in the olfactory epithelium. Chem Senses 2003;28(9):807-815

50 Smutzer G, Lee VM, Trojanowski JQ Arnold SE. Human olfactory mucosa in schizophrenia. Ann Otol Rhinol Laryngol 1998;107(4): 349-355

51 Lee VM, Pixley SK. Age and differentiation-related differences in neuron-specific tubulin immunostaining of olfactory sensory neurons. Brain Res Dev Brain Res 1994;83(2):209-215

52 Choi D, Li D, Law S, Powell M, Raisman G. A prospective observational study of the yield of olfactory ensheathing cells cultured from biopsies of septal nasal mucosa. Neurosurgery 2008;62(5): 1140-1144; discussion 1144-1145

53 Hahn CG, Han LY, Rawson NE, et al. In vivo and in vitro neurogenesis in human olfactory epithelium. J Comp Neurol 2005; 483(2):154-163

54 Takahashi S, Iwanaga T, Takahashi Y, Nakano Y, Fujita T. Neuronspecific enolase, neurofilament protein and S-100 protein in the olfactory mucosa of human fetuses. An immunohistochemical study. Cell Tissue Res 1984;238(2):231-234 
55 Calof AL, Bonnin A, Crocker C, et al. Progenitor cells of the olfactory receptor neuron lineage. Microsc Res Tech 2002; 58(3):176-188

56 Pixley SK. CNS glial cells support in vitro survival, division, and differentiation of dissociated olfactory neuronal progenitor cells. Neuron 1992;8(6):1191-1204

57 Hosaka Y, Yanase H, Iwanaga T. Morphological analysis of olfactory receptor cells using whole-mount preparations of the rat nasal mucosa. J Vet Med Sci 1998;60(8):897-904

58 Witt M, Bormann K, Gudziol V, et al. Biopsies of olfactory epithelium in patients with Parkinson's disease. Mov Disord 2009;24(6):906-914

59 Margolis FL. Olfactory marker protein (OMP). Scand J Immunol Suppl 1982;9:181-199

60 Nakashima T, Kimmelman CP, Snow JB Jr. Olfactory marker protein in the human olfactory pathway. Arch Otolaryngol 1985;111(5):294-297

61 Chuah MI, Zheng DR. Olfactory marker protein is present in olfactory receptor cells of human fetuses. Neuroscience 1987; 23(1):363-370

62 Sakai M, Ashihara M, Nishimura T, Nagatsu I. Carnosine-like immunoreactivity in human olfactory mucosa. Acta Otolaryngol 1990;109(5-6):450-453

63 Weiler E, Farbman AI. Supporting cell proliferation in the olfactory epithelium decreases postnatally. Glia 1998;22(4):315-328

64 Hegg CC, Irwin M, Lucero MT. Calcium store-mediated signaling in sustentacular cells of the mouse olfactory epithelium. Glia 2009;57(6):634-644

65 Hempstead JL, Morgan JI. Monoclonal antibodies to the rat olfactory sustentacular cell. Brain Res 1983;288(1-2): 289-295

66 Goldstein BJ, Schwob JE. Analysis of the globose basal cell compartment in rat olfactory epithelium using GBC-1, a new monoclonal antibody against globose basal cells. J Neurosci 1996; 16(12):4005-4016

67 Pixley SK, Farbman AI, Menco BP. Monoclonal antibody marker for olfactory sustentacular cell microvilli. Anat Rec 1997;248(3): 307-321

68 Minovi A, Witt M, Prescher A, et al. Expression and distribution of the intermediate filament protein nestin and other stem cell related molecules in the human olfactory epithelium. Histol Histopathol 2010;25(2):177-187

69 Mellert TK, Getchell ML, Sparks L, Getchell TV. Characterization of the immune barrier in human olfactory mucosa. Otolaryngol Head Neck Surg 1992;106(2):181-188

70 Golgi C. Sulla fina anatomia del bulbi olfattorii. Ti Rivista Sperimentale di Freniatria 1875;1:403-425

71 Blanes T. Sobre algunos puntos dudosos de la estructura del bulbo olfatorio. Rev Trim Micrograf 1898;3:99-127

72 Valverde F, Lopez-Mascaraque L. Neuroglial arrangements in the olfactory glomeruli of the hedgehog. J Comp Neurol 1991;307(4): 658-674

73 Doucette R. Glial cells in the nerve fiber layer of the main olfactory bulb of embryonic and adult mammals. Microsc Res Tech 1993; 24(2):113-130

74 Barber PC, Lindsay RM. Schwann cells of the olfactory nerves contain glial fibrillary acidic protein and resemble astrocytes. Neuroscience 1982;7(12):3077-3090

75 De Lorenzo AJ. Electron microscopic observations of the olfactory mucosa and olfactory nerve. J Biophys Biochem Cytol 1957;3(6): 839-850

76 Peters A, Palay SL, Webster Hde F, de Webster HF. The Fine Structure of the Nervous System: Neurons and Their Supporting Cells. 3th rev. ed. New York, NY: Oxford University Press; 1991

77 Raisman G. Specialized neuroglial arrangement may explain the capacity of vomeronasal axons to reinnervate central neurons. Neuroscience 1985;14(1):237-254
78 Doucette R. Development of the nerve fiber layer in the olfactory bulb of mouse embryos. J Comp Neurol 1989;285(4):514-527

79 Doucette JR. The glial cells in the nerve fiber layer of the rat olfactory bulb. Anat Rec 1984;210(2):385-391

80 Doucette R. Glial influences on axonal growth in the primary olfactory system. Glia 1990;3(6):433-449

81 Doucette R. PNS-CNS transitional zone of the first cranial nerve. J Comp Neurol 1991;312(3):451-466

82 Mori S, Leblond CP. Electron microscopic features and proliferation of astrocytes in the corpus callosum of the rat. J Comp Neurol 1969;137(2):197-225

83 Kott JN, Westrum LE, Raines EW, Sasahara M, Ross R. Olfactory ensheathing glia and platelet-derived growth factor B-chain reactivity in the transplanted rat olfactory bulb. Int J Dev Neurosci 1994;12(4):315-323

84 Ubink R, Halasz N, Zhang X, Dagerlind Å, Hökfelt T. Neuropeptide tyrosine is expressed in ensheathing cells around the olfactory nerves in the rat olfactory bulb. Neuroscience 1994;60(3): 709-726

85 Cummings DM, Brunjes PC. Migrating luteinizing hormone-releasing hormone (LHRH) neurons and processes are associated with a substrate that expresses S100. Brain Res Dev Brain Res 1995;88(2):148-157

86 Gong Q, Bailey MS, Pixley SK, Ennis M, Liu W, Shipley MT. Localization and regulation of low affinity nerve growth factor receptor expression in the rat olfactory system during development and regeneration. J Comp Neurol 1994;344(3): 336-348

87 Guenther J, Nick H, Monard D. A glia-derived neurite-promoting factor with protease inhibitory activity. EMBO J 1985;4(8): 1963-1966

88 Zurn AD, Nick H, Monard D. A glia-derived nexin promotes neurite outgrowth in cultured chick sympathetic neurons. Dev Neurosci 1988;10(1):17-24

89 Miragall F, Kadmon G, Husmann M, Schachner M. Expression of cell adhesion molecules in the olfactory system of the adult mouse: presence of the embryonic form of N-CAM. Dev Biol 1988;129(2):516-531

90 Doucette R. Immunohistochemical localization of laminin, fibronectin and collagen type IV in the nerve fiber layer of the olfactory bulb. Int J Dev Neurosci 1996;14(7-8):945-959

91 Kafitz KW, Greer CA. Role of laminin in axonal extension from olfactory receptor cells. J Neurobiol 1997;32(3):298-310

92 Liesi P. Laminin-immunoreactive glia distinguish regenerative adult CNS systems from non-regenerative ones. EMBO J 1985; 4(10):2505-2511

93 Franceschini IA, Barnett SC. Low-affinity NGF-receptor and E-N-CAM expression define two types of olfactory nerve ensheathing cells that share a common lineage. Dev Biol 1996;173(1):327-343

94 Barnett SC, Hutchins A-M, Noble M. Purification of olfactory nerve ensheathing cells from the olfactory bulb. Dev Biol 1993; 155(2):337-350

95 Vickland H, Westrum LE, Kott JN, Patterson SL, Bothwell MA. Nerve growth factor receptor expression in the young and adult rat olfactory system. Brain Res 1991;565(2):269-279

96 Boyd JG, Doucette R, Kawaja MD. Defining the role of olfactory ensheathing cells in facilitating axon remyelination following damage to the spinal cord. FASEB J 2005;19(7):694-703

97 Tomé M, Siladzic E, Santos-Silva A, Barnett SC. Calponin is expressed by subpopulations of connective tissue cells but not olfactory ensheathing cells in the neonatal olfactory mucosa. BMC Neurosci 2007;8:74

98 Guérout N, Derambure C, Drouot L, et al. Comparative gene expression profiling of olfactory ensheathing cells from olfactory bulb and olfactory mucosa. Glia 2010;58(13):1570-1580

99 Rela L, Bordey A, Greer CA. Olfactory ensheathing cell membrane properties are shaped by connectivity. Glia 2010;58(6):665-678 
100 Lakatos A, Franklin RJ, Barnett SC. Olfactory ensheathing cells and Schwann cells differ in their in vitro interactions with astrocytes. Glia 2000;32(3):214-225

101 Santos-Silva A, Fairless R, Frame MC, et al. FGF/heparin differentially regulates Schwann cell and olfactory ensheathing cell interactions with astrocytes: a role in astrocytosis. J Neurosci 2007;27(27):7154-7167

102 Tang ZP, Liu N, Li ZW, et al. In vitro evaluation of the compatibility of a novel collagen-heparan sulfate biological scaffold with olfactory ensheathing cells. Chin Med J (Engl) 2010;123(10):1299-1304

103 Anton ES, Weskamp G, Reichardt LF, Matthew WD. Nerve growth factor and its low-affinity receptor promote Schwann cell migration. Proc Natl Acad Sci U S A 1994;91(7):2795-2799

104 Caggiano M, Kauer JS, Hunter DD. Globose basal cells are neuronal progenitors in the olfactory epithelium: a lineage analysis using a replication-incompetent retrovirus. Neuron 1994;13(2):339-352

105 Schwob JE. Restoring olfaction: a view from the olfactory epithelium. Chem Senses 2005;30(Suppl 1):i131-i132

106 Farbman AI. Developmental biology of olfactory sensory neurons. Semin Cell Biol 1994;5(1):3-10

107 Graziadei PPC. Cell dynamics in the olfactory mucosa. Tissue Cell 1973;5(1):113-131

108 Roisen FJ, Klueber KM, Lu CL, et al. Adult human olfactory stem cells. Brain Res 2001;890(1):11-22

109 Lendahl U, Zimmerman LB, McKay RDG. CNS stem cells express a new class of intermediate filament protein. Cell 1990;60(4): 585-595

110 Doyle KL, Khan M, Cunningham AM. Expression of the intermediate filament protein nestin by sustentacular cells in mature olfactory neuroepithelium. J Comp Neurol 2001;437(2):186-195

111 Marshall CT, Lu C, Winstead W, et al. The therapeutic potential of human olfactory-derived stem cells. Histol Histopathol 2006; 21(6):633-643

112 Arnold SE, Han L-Y, Moberg PJ, et al. Dysregulation of olfactory receptor neuron lineage in schizophrenia. Arch Gen Psychiatry 2001;58(9):829-835

113 Carter LA, MacDonald JL, Roskams AJ. Olfactory horizontal basal cells demonstrate a conserved multipotent progenitor phenotype. J Neurosci 2004;24(25):5670-5683

114 Leung CT, Coulombe PA, Reed RR. Contribution of olfactory neural stem cells to tissue maintenance and regeneration. Nat Neurosci 2007;10(6):720-726

115 Mackay-Sim A, Kittel P. Cell dynamics in the adult mouse olfactory epithelium: a quantitative autoradiographic study. J Neurosci 1991;11(4):979-984

116 Mumm JS, Shou J, Calof AL. Colony-forming progenitors from mouse olfactory epithelium: evidence for feedback regulation of neuron production. Proc Natl Acad Sci U S A 1996;93(20):11167-11172

117 Graziadei PPC, Graziadei GA. Neurogenesis and neuron regeneration in the olfactory system of mammals. I. Morphological aspects of differentiation and structural organization of the olfactory sensory neurons. J Neurocytol 1979;8(1):1-18

118 Huard JM, Youngentob SL, Goldstein BJ, Luskin MB, Schwob JE. Adult olfactory epithelium contains multipotent progenitors that give rise to neurons and non-neural cells. J Comp Neurol 1998; 400(4):469-486

119 Lindsay SL, Riddell JS, Barnett SC. Olfactory mucosa for transplant-mediated repair: a complex tissue for a complex injury? Glia 2010;58(2):125-134

120 Duggan CD, Ngai J. Scent of a stem cell. Nat Neurosci 2007;10(6): 673-674

121 Weissman IL. Translating stem and progenitor cell biology to the clinic: barriers and opportunities. Science 2000;287(5457): $1442-1446$
122 Yamagishi M, Nakamura H, Takahashi S, Nakano Y, Iwanaga T. Olfactory receptor cells: immunocytochemistry for nervous system-specific proteins and re-evaluation of their precursor cells. Arch Histol Cytol 1989;52(Suppl):375-381

123 Jang W, Youngentob SL, Schwob JE. Globose basal cells are required for reconstitution of olfactory epithelium after methyl bromide lesion. J Comp Neurol 2003;460(1):123-140

124 Chen X, Fang H, SchwobJE. Multipotency of purified, transplanted globose basal cells in olfactory epithelium. J Comp Neurol 2004; 469(4):457-474

125 Yamagishi M, Nakamura H, Nakano Y, Kuwano R. Immunohistochemical study of the fourth cell type in the olfactory epithelium in guinea pigs and in a patient. ORL J Otorhinolaryngol Relat Spec 1992;54(2):85-90

126 Rowley JC III, Moran DT, Jafek BW. Peroxidase backfills suggest the mammalian olfactory epithelium contains a second morphologically distinct class of bipolar sensory neuron: the microvillar cell. Brain Res 1989;502(2):387-400

127 Miller ML, Andringa A, Evans JE, Hastings L. Microvillar cells of the olfactory epithelium: morphology and regeneration following exposure to toxic compounds. Brain Res 1995;669(1):1-9

128 Murrell W, Féron F, Wetzig A, et al. Multipotent stem cells from adult olfactory mucosa. Dev Dyn 2005;233(2):496-515

129 Delorme B, Nivet E, Gaillard J, et al. The human nose harbors a niche of olfactory ectomesenchymal stem cells displaying neurogenic and osteogenic properties. Stem Cells Dev 2010;19(6):853-866

130 Murrell W, Wetzig A, Donnellan M, et al. Olfactory mucosa is a potential source for autologous stem cell therapy for Parkinson's disease. Stem Cells 2008;26(8):2183-2192

131 Gomez G, Rawson NE, Hahn CG, Michaels R, Restrepo D. Characteristics of odorant elicited calcium changes in cultured human olfactory neurons. J Neurosci Res 2000;62(5):737-749

132 Audisio C, Raimondo S, Nicolino S, et al. Morphological and biomolecular characterization of the neonatal olfactory bulb ensheathing cell line. J Neurosci Methods 2009;185(1):89-98

133 Thompson RJ, Roberts B, Alexander CL, Williams SK, Barnett SC. Comparison of neuregulin-1 expression in olfactory ensheathing cells, Schwann cells and astrocytes. J Neurosci Res 2000;61(2): 172-185

134 Ramón-Cueto A, Avila J. Olfactory ensheathing glia: properties and function. Brain Res Bull 1998;46(3):175-187

135 Doucette R. Glial progenitor cells of the nerve fiber layer of the olfactory bulb: effect of astrocyte growth media. J Neurosci Res 1993;35(3):274-287

136 Goodman MN, Silver J, Jacobberger JW. Establishment and neurite outgrowth properties of neonatal and adult rat olfactory bulb glial cell lines. Brain Res 1993;619(1-2):199-213

137 Pixley SK. The olfactory nerve contains two populations of glia, identified both in vivo and in vitro. Glia 1992;5(4):269-284

138 Pixley SK. Characterization of olfactory receptor neurons and other cell types in dissociated rat olfactory cell cultures. Int J Dev Neurosci 1996;14(7-8):823-839

139 Chuah MI, Au C. Olfactory Schwann cells are derived from precursor cells in the olfactory epithelium. J Neurosci Res 1991; 29(2):172-180

140 Devon R, Doucette R. Olfactory ensheathing cells myelinate dorsal root ganglion neurites. Brain Res 1992;589(1):175-179

141 Gong Q, Liu W-L, Srodon M, Foster TD, Shipley MT. Olfactory epithelial organotypic slice cultures: a useful tool for investigating olfactory neural development. Int J Dev Neurosci 1996;14(78):841-852

142 Ramón-Cueto A, Pérez J, Nieto-Sampedro M. In vitro enfolding of olfactory neurites by p75 NGF receptor positive ensheathing cells from adult rat olfactory bulb. Eur J Neurosci 1993;5(9):1172-1180 